\title{
الفاصلة القرآنية بين الانسجام البلاغي والسياق التفسيري(دراسة للفاصلة القرآنية في الآيات المتماثلة)
}

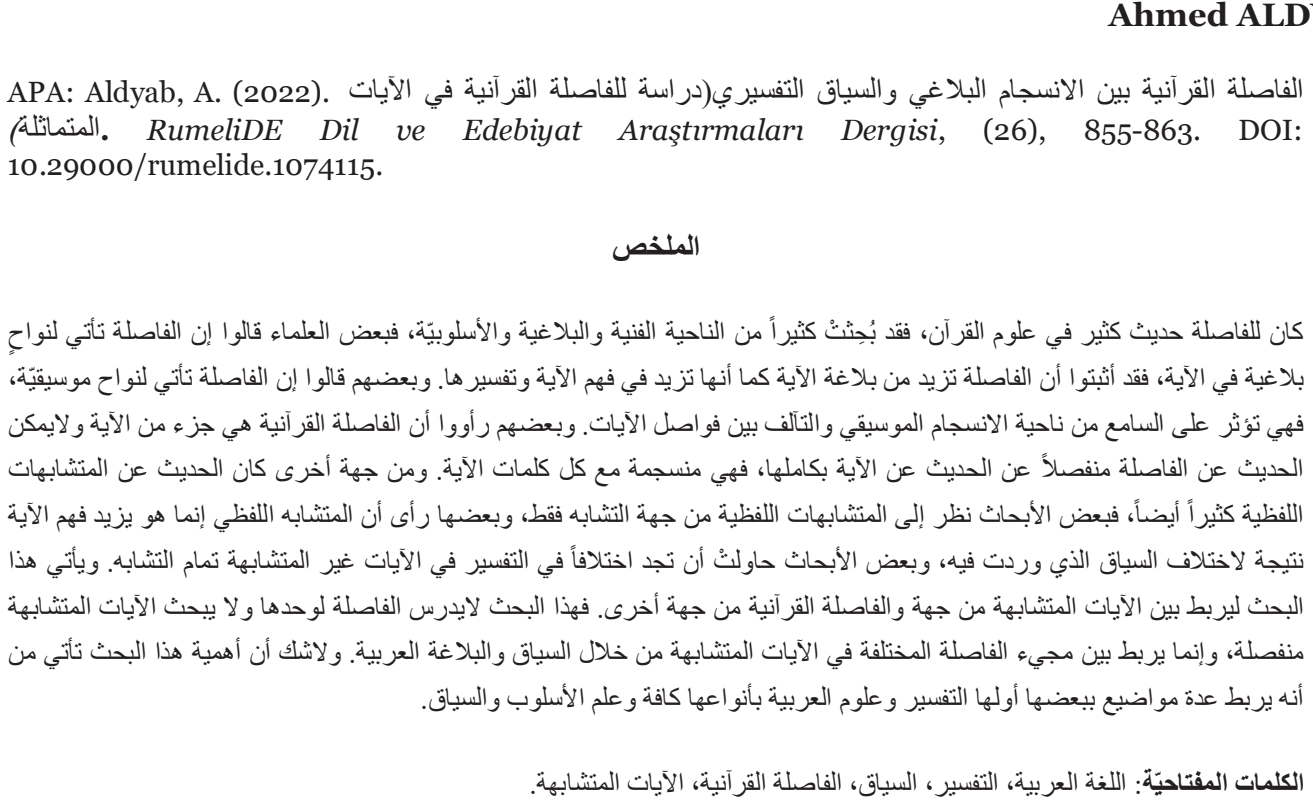

\section{2-Belâğî uyum ve tefsir bağlamı arasında Kur’ân fâsılası (Benzer ayetlerde Kur'ân fâsılası üzerine bir araştırma)}

\section{$\ddot{O} \mathbf{z}$}

Fâsıla, Kur'an ilimleri arasında çokça üzerinde durulan bir konu olup sanat, belagat ve üslup açısından araştırılmıştır. Bir grup alim, fâsılanın ayetin belagatini kuvvetlendirmek için geldiğini söylemekle beraber ayetin anlaşılması noktasında tefsirini de güçlendirdiğini belirtmişlerdir. Bazı âlimler ise fâsılanın makam ve müzikal gerekçelerle geldiğini belirterek dinleyiciyi melodik, ahenk ve ayet sonlarının uyumu yönüyle etki altına aldığını öne sürmüşlerdir. Bazı âlimler de fâsılanın ayetin bir parçası olduğunu , ayetten ayrı düşünülemeyeceğini ve ayetin tüm kelimeleriyle uyumlu olduğunu vurgulamışlardır. Kur'an ilimleri içerisinde yer alan konulardan birisi de "müteşabih ayetler" konusudur. Bazı araştırmalar bu konuyu sadece benzerlik yönüyle ele almıştır. Bazı araştırmalar ise müteşabih ayetlerin bağlamıyla ilgilenerek ayeti anlamada bağlamın önemi üzerinde durmuştur. Bazı araştırmalar da tam benzerlik göstermeyen müteşabih ayetlerin tefsirinde farklılık tespit etmeye çalışmıştır. Bu araştırma, fâsıla konusunu ve müteşabih ayet konusunu tek başına ele almamaktadır. Bağlam ve belagat aracılığıyla" fâsıla- müteşabih ayet " ilişkisini incelemektedir. Bu araştırmanın önemi, konu ele alınırken tefsir, Arapça belagati, üslup ilmi ve bağlam ilimleri çerçevesinde kalmasidır.

Anahtar kelimeleri: Arapça, Tefsir, Bağlam, Kur’an fâsılası, Müteşabih ayetler

Dr. Öğr. Üyesi, Ankara Yıldırım Beyazıt Üniversitesi, İnsan ve Toplum Bilimleri Fakültesi, Arapça Mütercim Tercümanlı (Ankara, Türkiye), ahmad.adyab@gmail.com, ORCID ID: 00oo-ooo2-9497-9197 [Araştırma makalesi, Makale kayıt tarihi: 08.01.2022-kabul tarihi: 20.02.2022; DOI: 10.29000/rumelide.1074115]

Adres $\mid$ Address

RumeliDE Dil ve Edebiyat Araştırmaları Dergisi $\quad$ RumeliDE Journal of Language and Literature Studies

Osmanağa Mahallesi, Mürver Çiçeği Sokak, No:14/8 $\quad$ Osmanağa Mahallesi, Mürver Çiçeği Sokak, No:14/8

Kadıköy - İSTANBUL / TÜRKIYE 34714 Kadıköy - ISTANBUL / TURKEY 34714

e-posta: editor@rumelide.com e-mail: editor@rumelide.com,

tel: +90 5057958124, +902167730616 phone: +90 5057958124, +90 2167730616 


\title{
Last words of the Quran verses in terms of rhetorical harmony and tafsir (A study on the last words of similar verses in the Qur'an)
}

\begin{abstract}
End rhyme is a subject which has been discussed mostly among the quranic sciences and it has been searched from the point of view art, rhetoric and genre. Some of the scholars have said that end rhyme's role is to strengthen the rhetoric of quranic verses. At the same time they have claimed that it strengthens the tafseer to be understood the verses. They have also claimed that end rhymes appear to effect the audience with it's rhymes. Because the harmony which has been occured with end rhymes has created aesthetics and beauty. Some scholars have said that the end rhymes are the parts of the quranic verses and emphasized that it is impossible to separate the verses and the end rhymes. Allehorical verses are one of the quranic sciences. Some researches have dealt with this subject from the point of view smile. Some other researches have dealt with allegorical verses in their Context . They have emphasized that the Context is very important to understand the quranic verses. This study deals with not only end rhymes and allegorical verses but also the relationship between end rhymes and allegorical verses through rhetoric. The importance of this study is that the subject has been discussed in the framework of tafseer, arabic rhetoric, genre and Context sciences.
\end{abstract}

Keywords: Arabic, Tafseer, Context, End rhymes, Allegorical verses



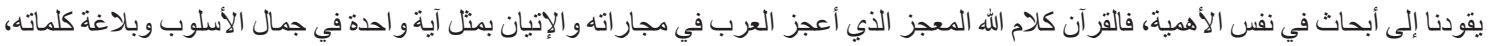

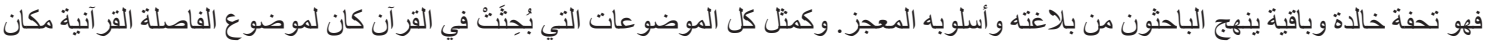

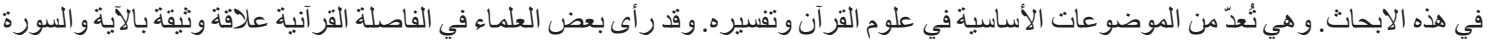

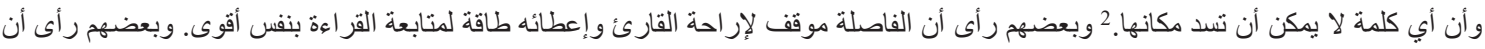

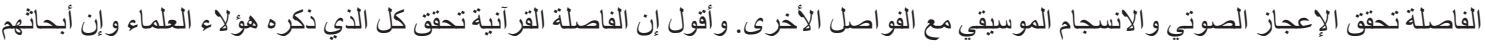

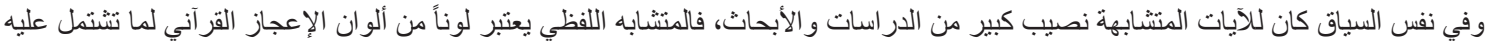

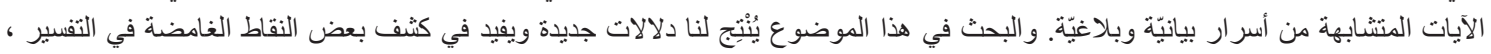

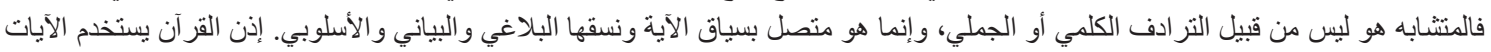

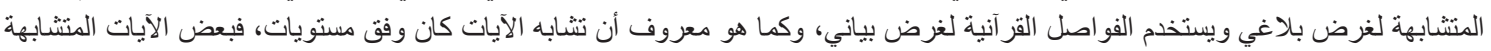

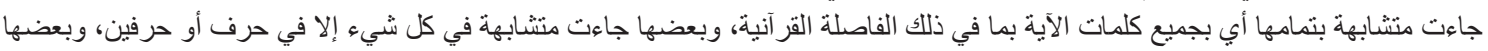

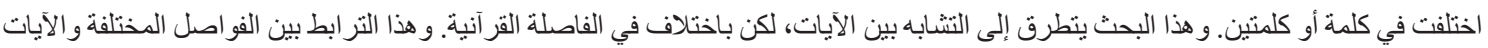

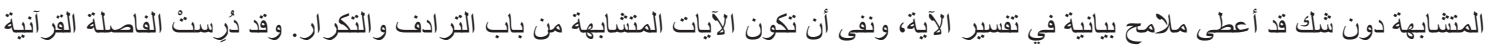

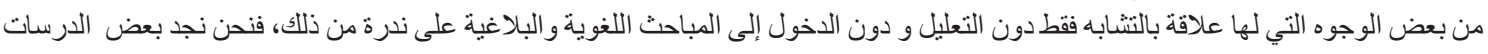

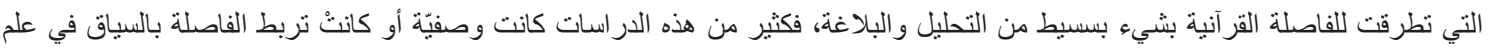

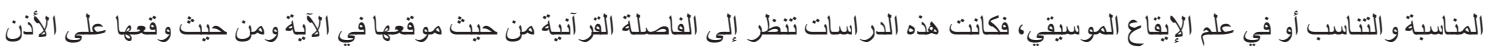

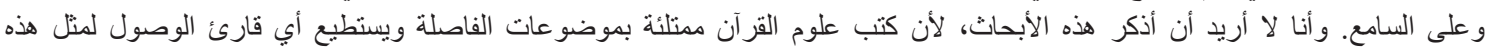
الموضو عات.

Adres
RumeliDE Dil ve Edebiyat Arassttrmaları Dergisi
Osmanağa Mahallesi, Mürver Çiçeği Sokak, No:14/8
Kadıköy - İSTANBUL / TÜRKIYE 34714
e-posta: editor@rumelide.com
tel: +90 $5057958124+902167730616$ 
RumeliDE Dil ve Edebiyat Araştırmaları Dergisi 2022.26 (Şubat)/ 857 Belâğî uyum ve tefsir bağlamı arasında Kur'ân fâsılası (Benzer ayetlerde Kur'ân fâsılası üzerine bir araştırma) / A. Aldyab (855863. s.)

حاولتُ في هذه الدر اسة أن أتجنب التوصيف قدر الإمكان وأعطيت أهمية للتعليل وذكر الأسباب. وفي الحقيقة هذا الذي ينقص مثل هذه الدراسات

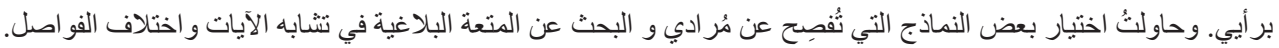

يقول الله تعالى في سورة إبرا هيم

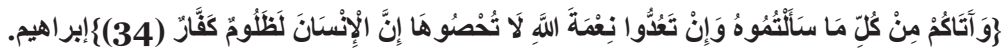

ويقول تعالى في سورة النحل



نلاحظ أن الآيتين منتابهتان إلى حد الفاصلة التي افترقت و اختلفتُ بينهما. لو نظرنا إلى سياق آية إبر اهيم نجد أن بعض الآيات تدخل في كفر الإنسان

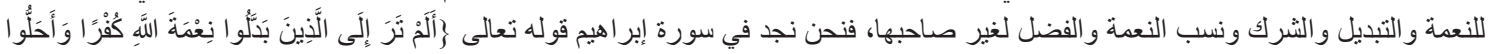

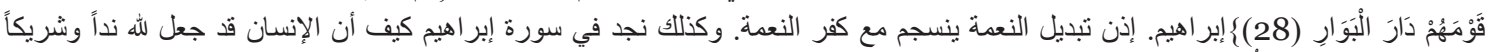

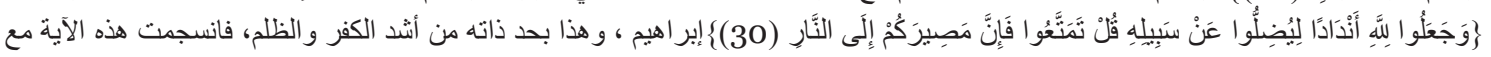

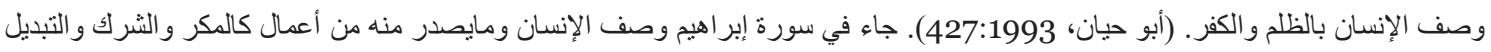

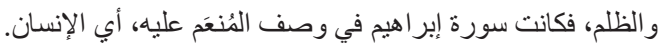

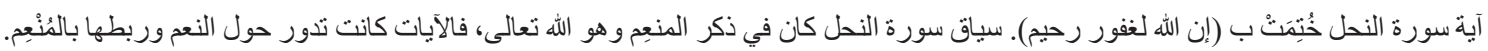

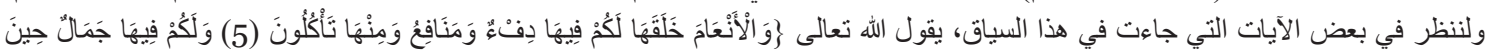

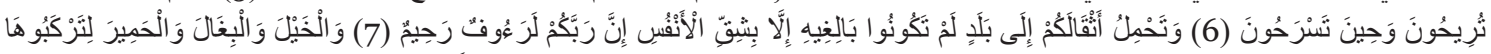

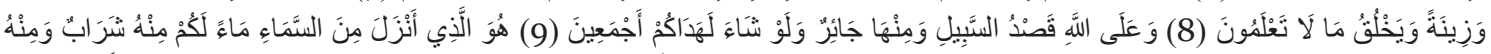

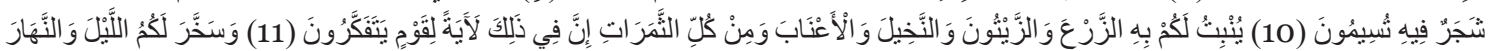

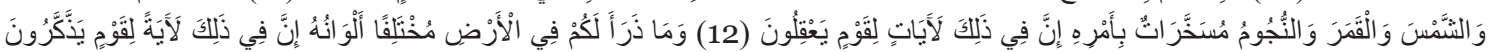

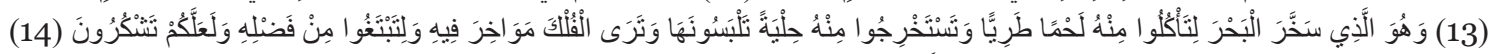

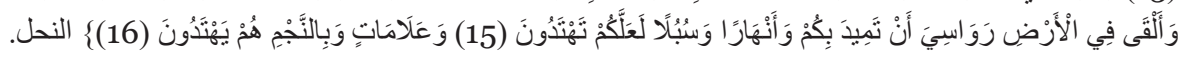

إذن هذه الآيات تذكر النعم من وجه التفضيل و الامتنان و هذه الحال يناسبها ذكر المغفرة والرحمة، لأنها في الأساس كانت لهذا الهذف في سورة النحل.

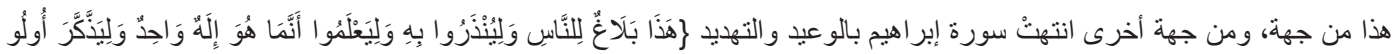

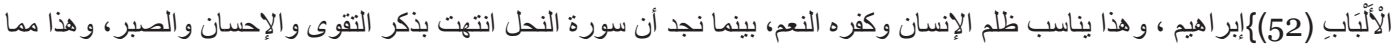

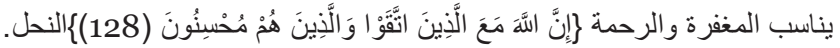

و الحديث عن هاتين الآيتين مجتمعتين يشكل مفهوم العلاقة بين الإنسان وربه، فالإنسان يصدر منه الظلم لنفسه وللآخرين ويكفر بنعم الله الرحيم، والله عز وجل يقابله بالمغفرة و الرحمة.

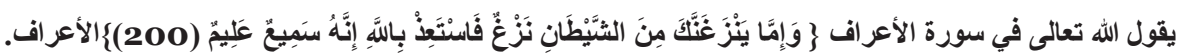

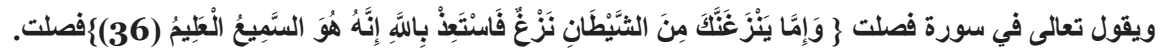

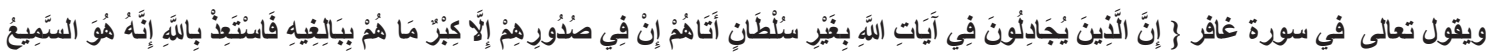

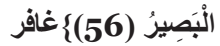

نلاحظ أن التشابه بين آية الأعر اف وآية سورة فصلت تشابه تام بالكلمات والفو اصل، بينما اختلفت هاتان الآيتان عن آية سورة غافر.

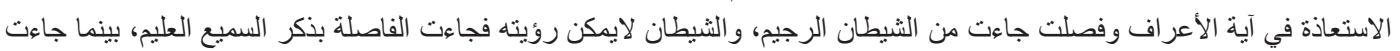

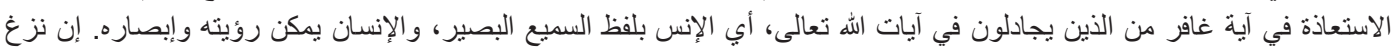

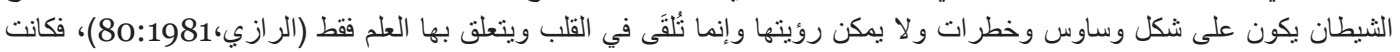

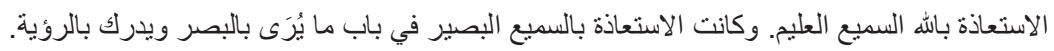

\footnotetext{
\begin{tabular}{r|l} 
Adres & Address \\
RumeliDE Dil ve Edebiyat Araştırmaları Dergisi & RumeliDE Journal of Language and Literature Studies
\end{tabular} Osmanağa Mahallesi, Mürver Çiçeği Sokak, No:14/8 Osmanağa Mahallesi, Mürver Çiçeği Sokak, No:14/8 Kadıköy - İSTANBUL / TÜRKIYE 34714 Kadıköy - ISTANBUL / TURKEY 34714

e-posta: editor@rumelide.com e-mail: editor@rumelide.com,

tel: +90 5057958124, +902167730616 phone: +90 5057958124, +902167730616
} 


\section{8 / RumeliDE Journal of Language and Literature Studies 2022.26 (February)}

Last words of the Quran verses in terms of rhetorical harmony and tafsir (A study on the last words of similar verses in the Qur'an) / A. Aldyab (pp. 855-863)

من النكت البلاغية التي يمكن أن نستشفّها من تكامل فواصل الآيات أنها تجمع السمع و البصر و العلم، و هذه الصفات تحقق كل معاني

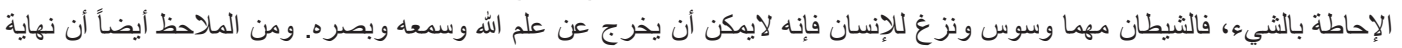

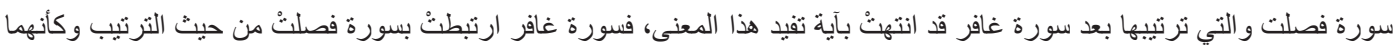

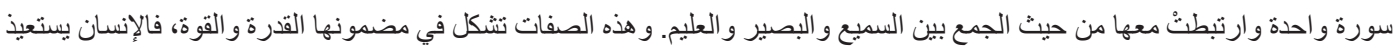

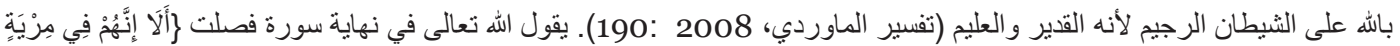

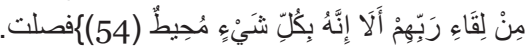

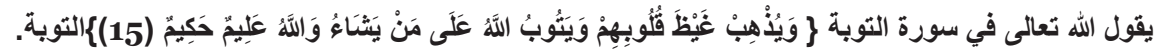

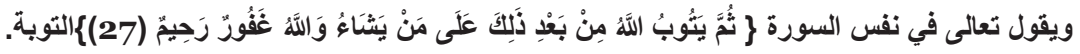

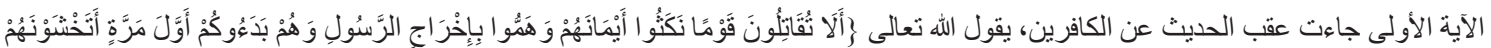

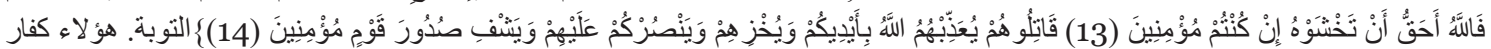

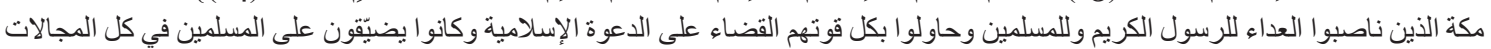

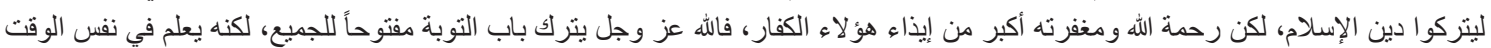

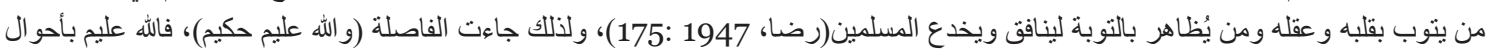

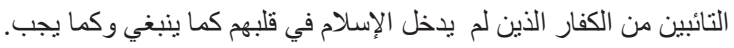

أما الآية الثانية فقد جاءت في سياق تولَّي المسلمين وتخلفهم في غزوة حنين بعد أن أعجِبوا بعددهم واغتروا بكثرتهم، فكان التولي منهم نتيجة الإحباط

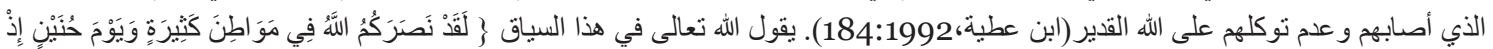

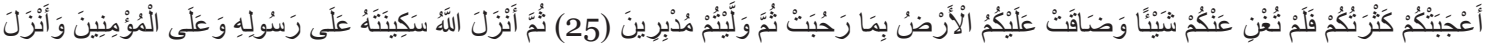

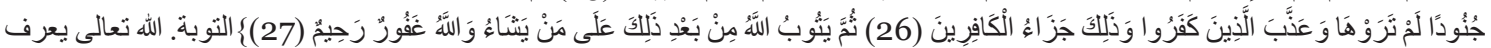

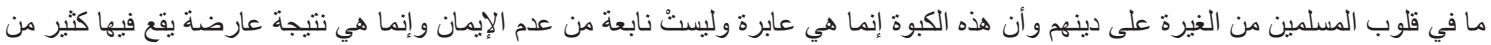

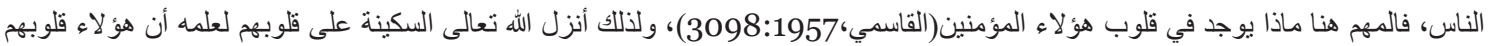


جاءتْ الفاصلة بهذا الثكل ر أفة بقلوبهم وتطيباً لخاطر هم.

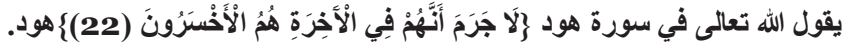

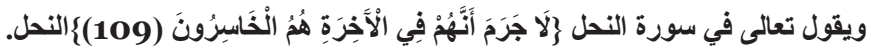

لكي نفهم الفرق بين الفاصلتين، لا بد أن نوضح أولاً الفرق بين هاتين الصيغتين، صيغة اسم التفضيل، وصيغة اسم الفاعل. صيغة اسم التفضيل

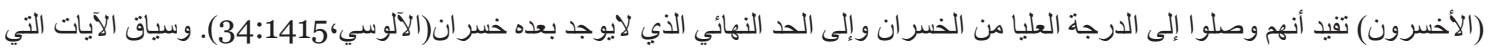

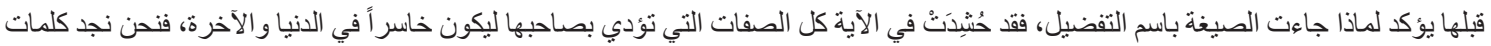


مضاعفة العذاب، عدم السمع والبصر في الدنيا والآخرة، خسارة النفس).

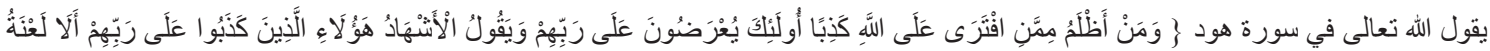

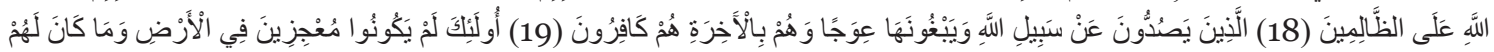

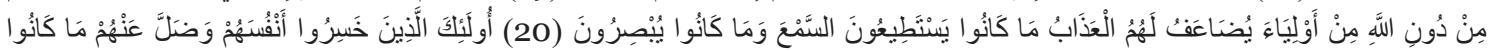

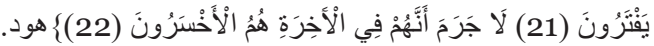

هؤلاء القوم كانوا يصدون أنفسهم عن طاعة الله ويصدون الآخرين عن الدخول في الإسلام، فهم لم يكتفو ا بمنع أنفسهم من الدخول في دين الله و إنما

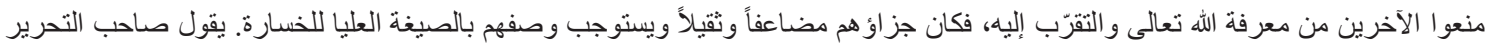

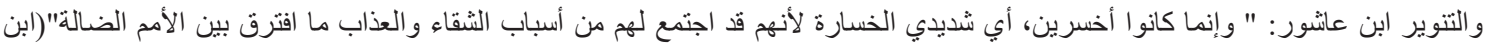

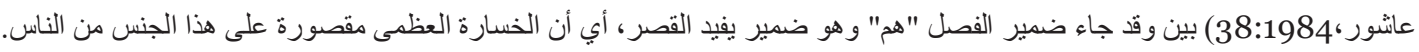

\footnotetext{
Adres $\mid$ Address

RumeliDE Dil ve Edebiyat Araştırmaları Dergisi $\quad$ RumeliDE Journal of Language and Literature Studies Osmanağa Mahallesi, Mürver Çiçeği Sokak, No:14/8 $\quad$ Osmanağa Mahallesi, Mürver Çiçeği Sokak, No:14/8 Kadıköy - İSTANBUL / TÜRKIYE 34714 Kadıköy - ISTANBUL / TURKEY 34714 e-posta: editor@rumelide.com e-mail: editor@rumelide.com, tel: +90 5057958124, +902167730616 phone: +90 5057958124, +90 2167730616
} 
RumeliDE Dil ve Edebiyat Araştırmaları Dergisi 2022.26 (Şubat)/ 859 Belâğî uyum ve tefsir bağlamı arasında Kur'ân fâsılası (Benzer ayetlerde Kur'ân fâsılası üzerine bir araştırma) / A. Aldyab (855-

فاصلة آية النحل (الخاسرون) جاءت بصيغة اسم الفاعل و هي صيغة خبريّة. السياق قبل آية النحل يبين أن هؤلاء الذين استحقوا الخسارة كان يبدر

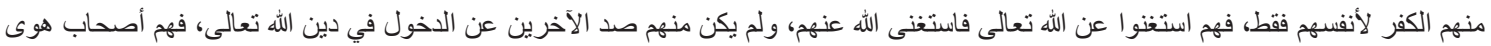
استحبو ا الحياة الدنيا على الآخرى وكانو ا غافلين عن الطاعة و العبادة.

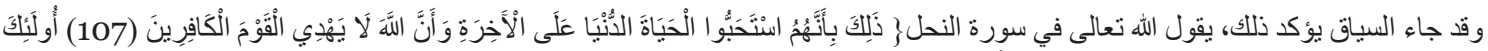

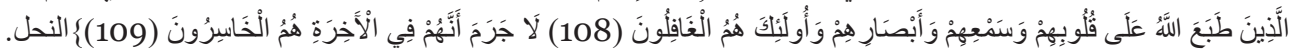

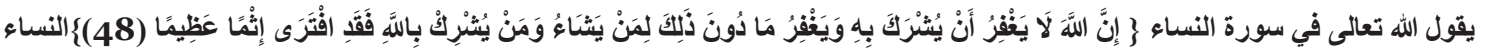

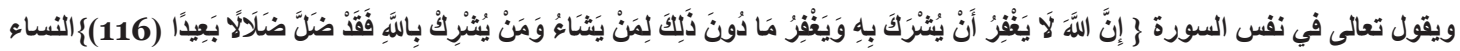

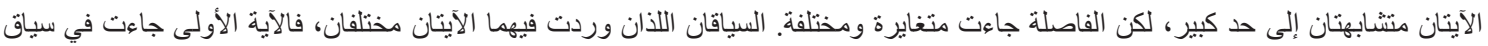

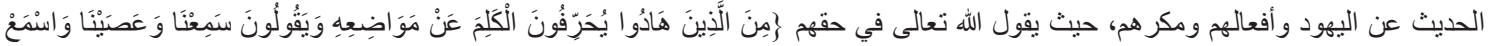

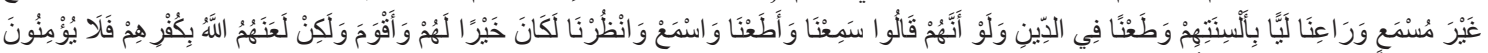

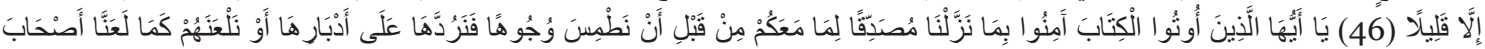





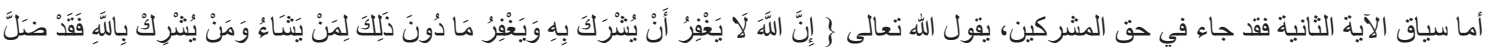

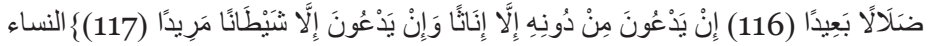

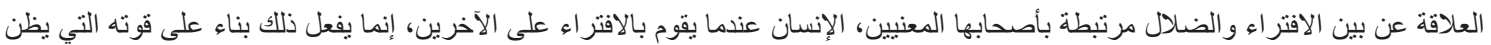

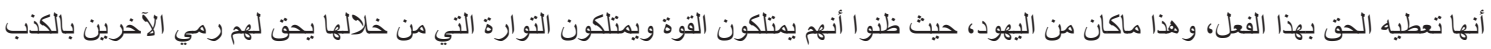

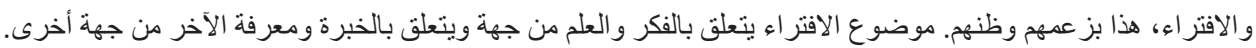

ومن هنا كان اليهود يحرفون الكلم عن مواضعه ليو افق أهو اءهم، فهم فعلوا هذا الفعل عن علم ومعرفة مسبقة. اليهود أصحاب كتاب، و هذا الكتاب

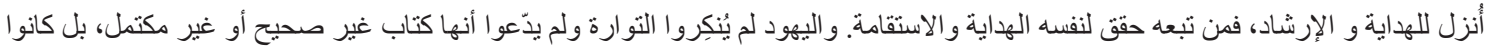

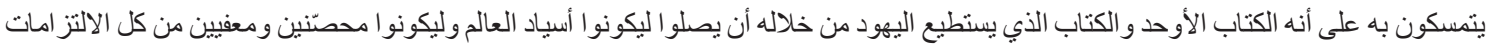
و الو اجبات، من هنا جاء تحريفهم للتور اة لاقتناعهم بأنهم غير مسؤولين عن هذا أمام الله تعالى، ولهذا جاءت الكات الفاصلة القر آنية متناسبة مع فكر هم وفعلهم.

أما بالنسبة لموضوع الضلال فهو يتعلق بالجهل، والجهل كما هو معروف بضاعة يتمسك بها صاحبها على أنها الأصحّ و أنها البضاعة الأفضل.

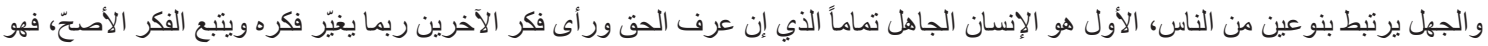

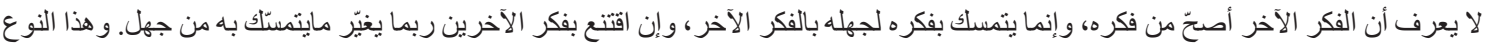

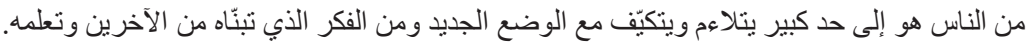

و النوع الثاني من الإنسان الجاهل هو من يتمسك بفكره على أنه الأصحّ والأفضل وعرف في نفس الوقت أن الفكر الآخر هو أيضاً صحيح، لكنه

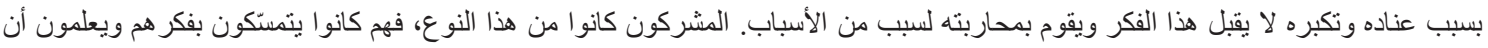

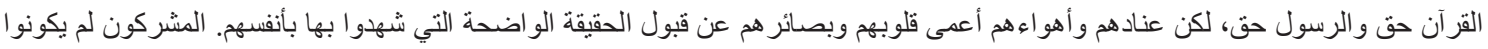

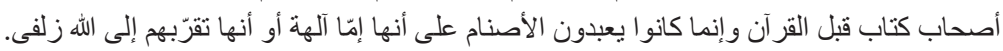

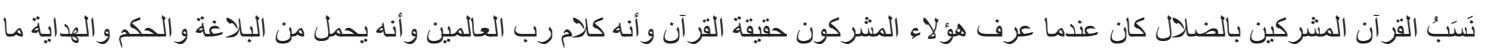

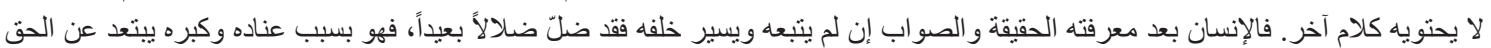

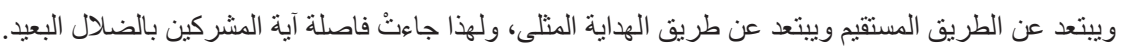

Adres Address

RumeliDE Dil ve Edebiyat Araşturmaları Dergisi Osmanağa Mahallesi, Mürver Çiçeği Sokak, No:14/8 Kadıköy - İSTANBUL / TÜRKIYYE 34714 tel: + e-posta: editor@rumelide.com

RumeliDE Journal of Language and Literature Studies Osmanağa Mahallesi, Mürver Çiçeği Sokak, No:14/8 Kadıköy - ISTANBUL / TURKEY 34714

e-mail: editor@rumelide.com,

phone: +90 505 7958124, +90 2167730616 
860 / RumeliDE Journal of Language and Literature Studies 2022.26 (February)

Last words of the Quran verses in terms of rhetorical harmony and tafsir (A study on the last words of similar verses in the Qur'an) / A. Aldyab (pp. 855-863)

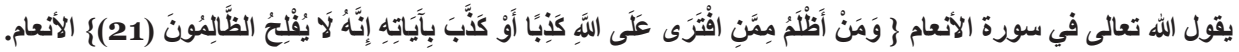

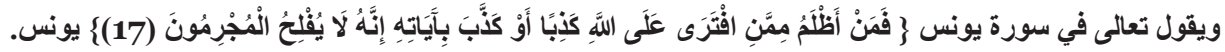

لو نظرنا إلى السياق الذي وردت فيه آية الأنعام لوجدنا أن هذه الفاصلة مناسبة لهذا السياق الذي وردت فيه وقد حققت القيمة البلاغية في الآية و افترقت

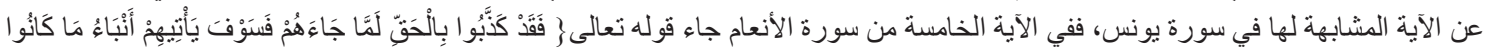

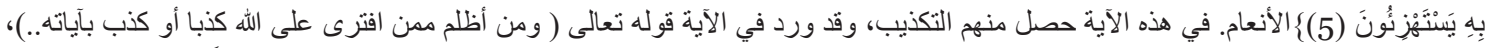

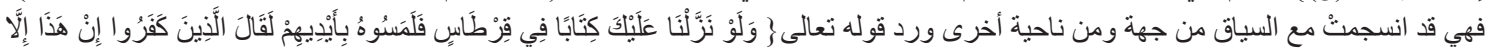

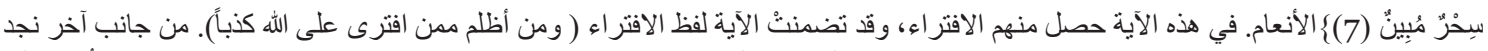

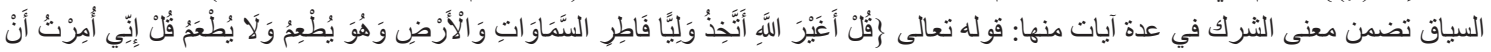

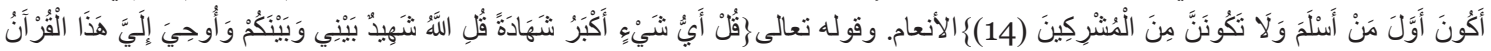

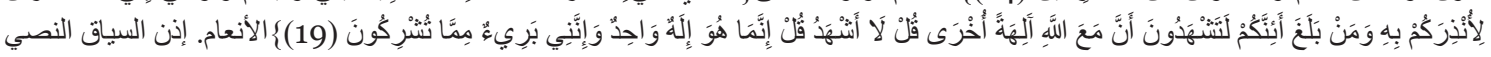

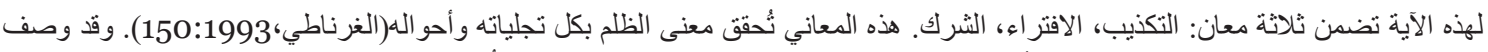

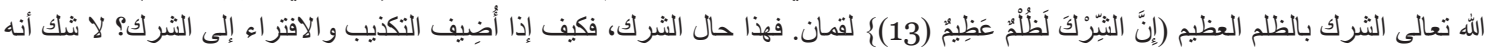
سيكون ظلم أعظم و أكبر.

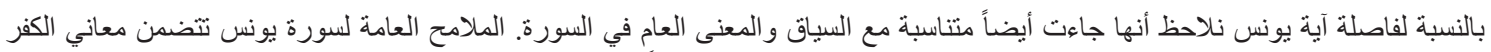

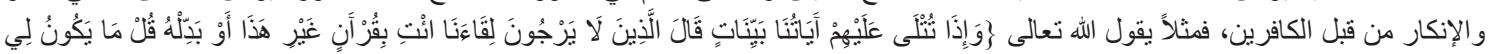

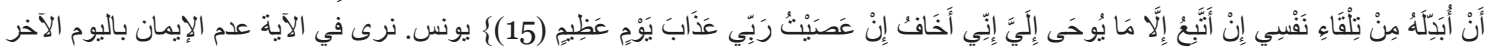

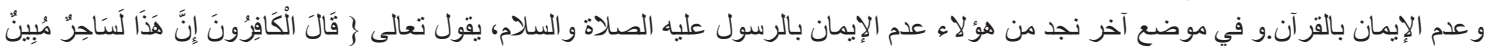

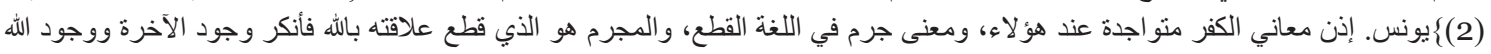

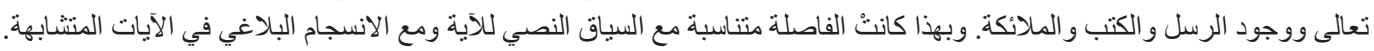

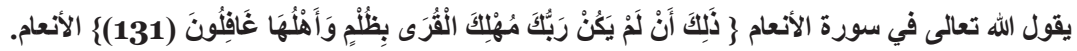

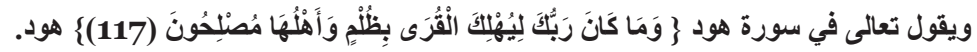





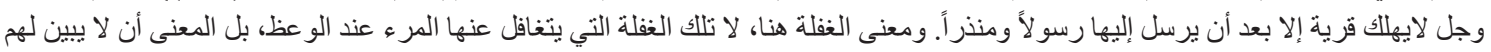



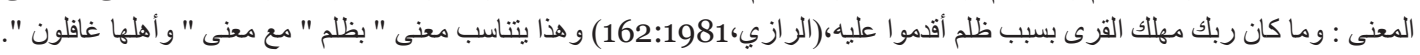

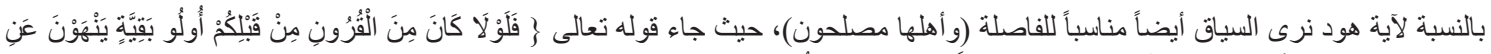

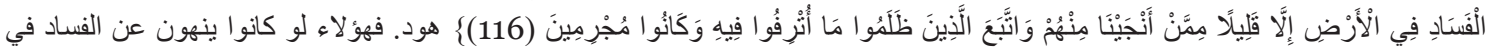
الأرض أو كانوا مصلحين لما أهلكهم الله عز وجل، ولذلك جاءت الفاصلة مناسبة للسياق وللانسجام البياني.

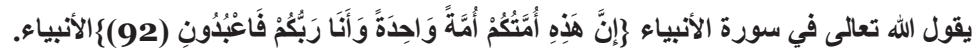

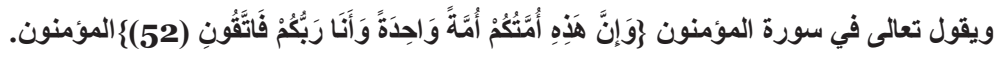

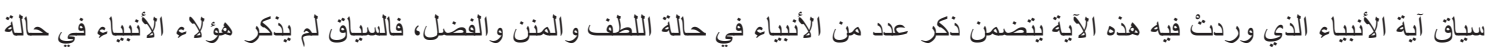



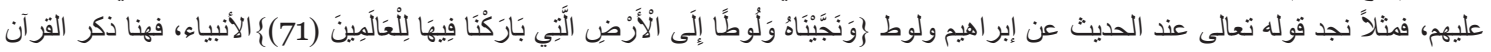

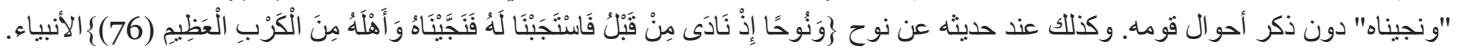

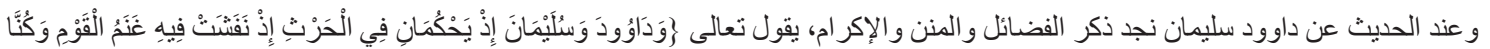

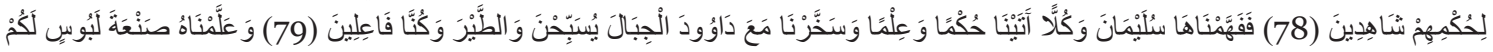

\footnotetext{
Adres Address

RumeliDE Dil ve Edebiyat Araşttrmaları Dergisi $\quad$ RumeliDE Journal of Language and Literature Studie Osmanağa Mahallesi, Mürver Çiçeği Sokak, No:14/8 Osmanağa Mahallesi, Mürver Çiçeği Sokak, No:14/8 Kadıköy - İSTANBUL / TÜRKIYE 34714 Kadıköy - ISTANBUL / TURKEY 34714

tel: +90 5057958124, +90 2167730616 phone: +90 5057958124, +90 2167730616
} 
RumeliDE Dil ve Edebiyat Araştırmaları Dergisi 2022.26 (Şubat)/ 861 Belâğî uyum ve tefsir bağlamı arasında Kur'ân fâsılası (Benzer ayetlerde Kur'ân fâsılası üzerine bir araştırma) / A. Aldyab (855-

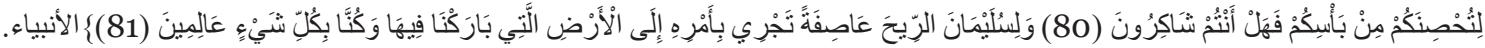

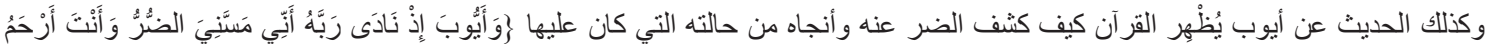

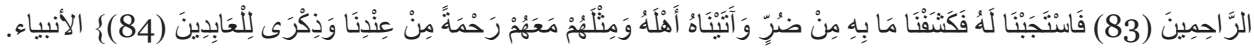

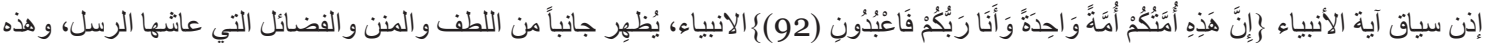

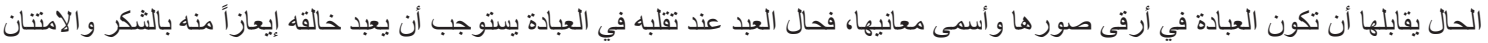

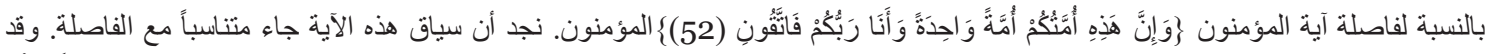

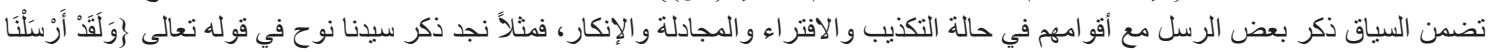

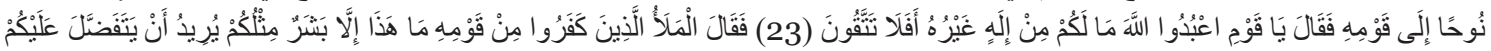

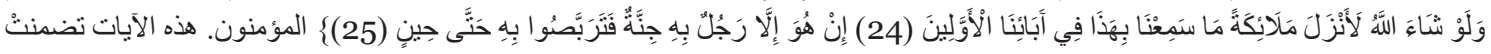

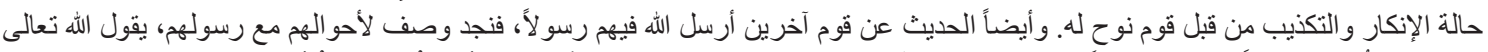

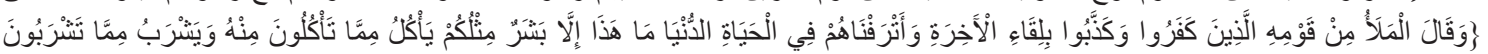

(33)

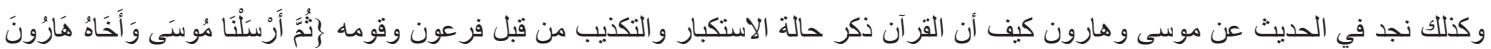



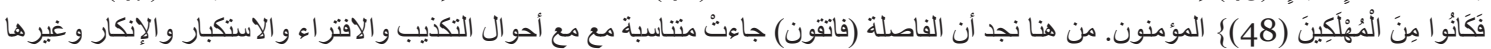

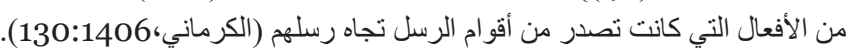

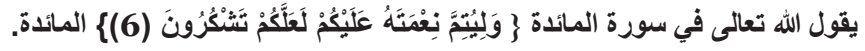

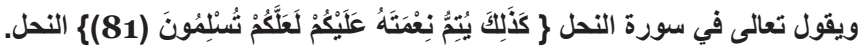

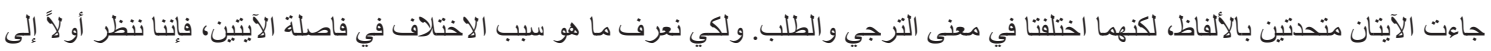



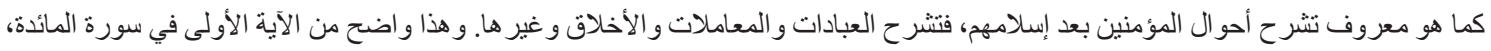

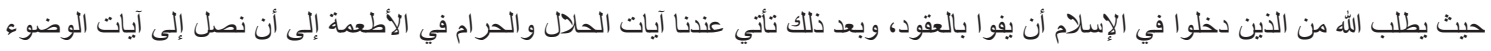

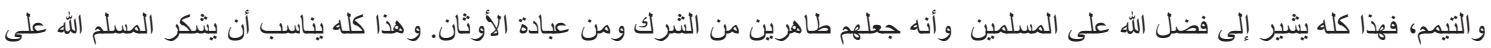

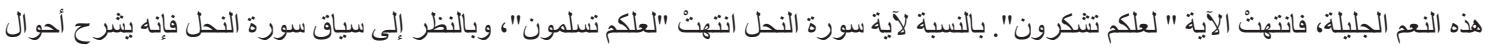

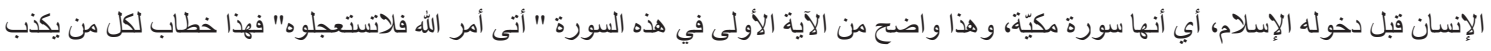

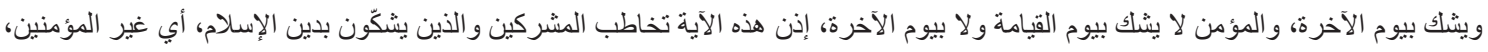

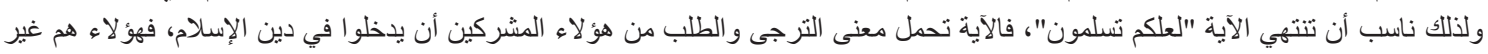
مسلمين أصلاً ولذلك جاءتُ الفاصلة مناسبة لحالهم.

الخاتمة

بعد البحث و الدر اسة توصل الباحث إلى النتائج التالية:

موضوع الفاصلة القرآنية من الموضو عات التي ترتبط بمواضيع عديدة ومختلفة، فهي تتعلق بالسياق النصي والبلاغة العربية وهي ترتبط بأسباب النزول، فبعض الفو اصل القر آنية يمكن تحديد معناها و علاقتها بالآية من خلال أسباب النزول.

اهنم العلماء بالجانب الجمالي للفاصلة على تفاوت فيما بينهم، ولم يفرد كثير من هؤلاء العلماء للفاصلة كتباً خاصة بها من حيث البحث الجمالي، و إنما

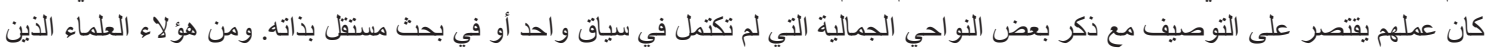

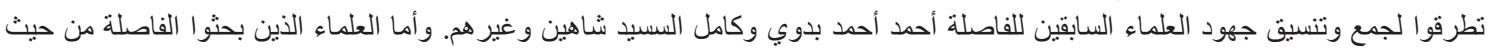

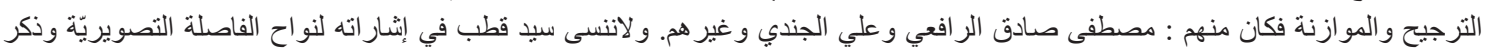
إيقاعها في علم التناسب و المناسبة في الآية.

RumeliDE Dil ve Edebiyat Arasturmates Address Osmanağa Mahallesi, Mürver Çiçeği Sokak, No:14/8 Kadıköy - İSTANBUL / TÜRKIYYE 34714 e-posta: editor@rumelide.com tel: +90 505 7958124, +90 2167730616

RumeliDE Journal of Language and Literature Studies

Osmanağa Mahallesi, Mürver Çiçeği Sokak, No:14/8

Kadıköy - ISTANBUL / TURKEY 34714

e-mail: editor@rumelide.com,

phone: +90 $5057958124,+902167730616$ 
862 / RumeliDE Journal of Language and Literature Studies 2022.26 (February)

Last words of the Quran verses in terms of rhetorical harmony and tafsir (A study on the last words of similar verses in the Qur'an) / A. Aldyab (pp. 855-863)

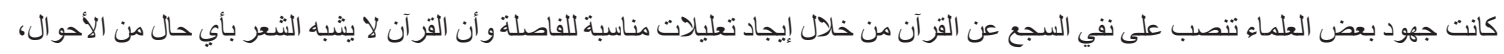

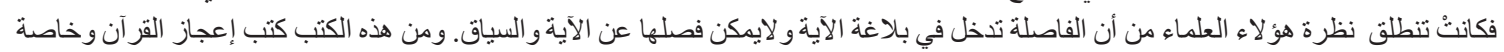

الإعجاز البياني.

كما رأينا كان القرآن يستخدم الفاصلة بما يتناسب مع الآية والسياق، ليس هذا فحسب، وإنما كان يوفق بين الإيقاع الموسيقي للفاصلة وبين المعنى، فكانت الفاصلة تحقق البلاغة اللغوية و الانسجام السياقي والتناسب اللفظي.

لا بد للقارئ أو الحافظ أن يمتلك معرفته للسياق و أسباب النزول لكيلا يُخطئ أثناء القراءة وتتثابه عليه الآيات الدتماتلة باللفظ.

للفاصلة القر آنية وظائف عديدة في الآية، فهي لم تأت لمجرد الثكل و التناسب الموسيقي، بل هي تقوم بوظيفة نصيّة تخدم المعنى التفسيري ووظيفة

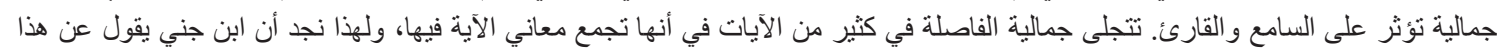

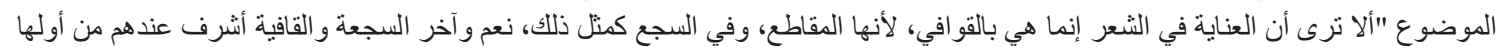

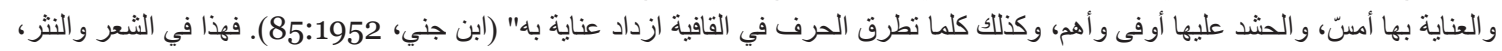
فكيف بالقرآن الذي يمثلك بلاغة ما بعدها بلاغة.

من النتائج المهمة التي توصل إليها الباحث أن موضوع التثابه اللفظي في القرآن لم يُعَتَى به بالثكل الكافي، فنحن نجد بعض الكتب التي جمعتُ

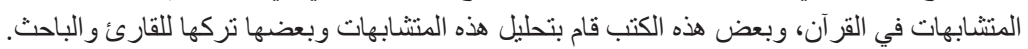

المتثابهات اللفظية لها دور كبير فهم أسلوب القرآن وبلاغته. و هذه المتشابهات جاءت في موضو عات آنات مختلفة من القرآن، فهي موجودة في القصص القر آني وفي بعض آيات الآحكام، ولهذا فهي يمكن أن تجيب عن أسئلة كثيرة في فهم هذه الموضو عات التهات و التوصل إلى فهم جديد ونكات بلاغيّة مهمة.

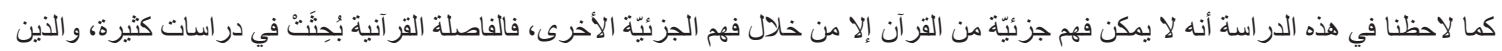

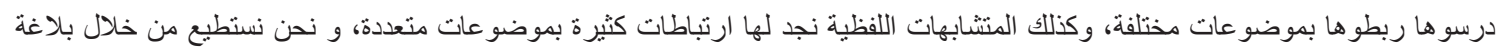

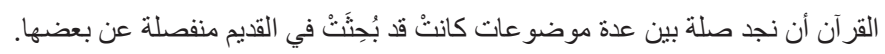
المصادر والمراجع ابن جرير الطبري، 1991، تفسير الطبري، مؤسسة الرسالة، بيروت.

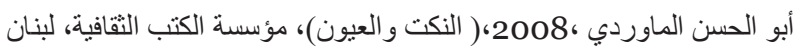
أبو الفتح عثمان بن جني،1952، الخصائص، دار الكتب المصرية. أبو جعفر ، أحمد بن إبر اهيم ابن الزبير الغرناطي، بن، 1993، ملاك التأويل، دار الكتب العالمية، بيروت.

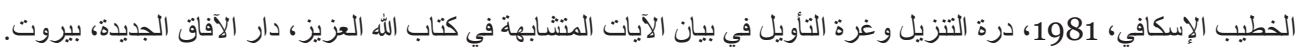

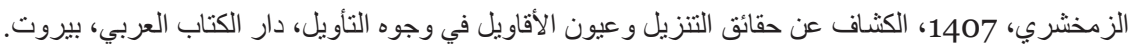



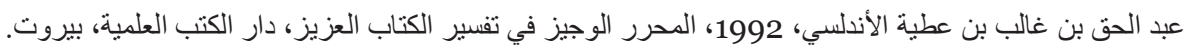
فخر الدين الرازي، 1981،مفاتيح الغيب، دار الفكر ، دمثق. القاسمي محمد جمال الدين، 1957، محاسن التأويل، دار البابي الحلبي. محمد الطاهر بن عاثنور، 1984، التحرير والتنوير ، الدار التونسية للنشر، بتونس. محمد بن يوسف بن حبان، 1993، البحر المحيط، دار الكتب العلمية، بيروت. محمد رشيد رضا، 1947، تفسير المنار، مطبعة المنار، مصر. محمود بن حمزة الكرماني، 1406، البرهان في توجيه متشابه القرآن، دار الكتب العلمية،بيروت. 


\section{Bibliyografya}

Mahmud al-Karamani (1406). Al-Burhan fi Mutashabah al-Qur'an, Beyrut.

Âlûsî, Ebu’l Fadl Şihâbuddîn Mahmûd (2001). Rûhu’l-me‘ânî fi tefsîri’l-Kur'âni’l-'Azîm, Beyrut.

Cemâleddin el-Kāsımî (1957). Mehâsinü't-tevîll, Beyrut.

Ebû Hayyân Endelûsî \& Muhammed b. Yusuf b. Ali (1993). Bahru’l-muhît. Beyrut : Dâru’l-Kütübi’l'İlmiyye.

Ebû Muhammed Abdülhak b. Gālib b. Abdirrahmân b. Gālib el-Muhâribî el-Grrnâtî el-Endelüsî (1992). el-Muharrerül-vecîz, Beyrut.

İbn Âşûr, Muhammed Tahir (1984). et-Tahrir ve’t-Tenvir, Tunus.

İbn Cinnî (1952). el-Hașâ iș, Kahire.

İbn Kesîr, İsmail b. Amr Ed-Dımaşkî (1994). Tefsîru’l-Kur'âni’l-Azîm. Riyâd : Daru Selam.

Kurtubî, Muhammed b. Ahmed (1966). el-Câmi‘u li ahkâmi’l-Kur'ân, Mısır.

Râzî, Fahruddîn Muhammed (1981). Mefâtihu’l-ğayb (et-Tefsîru'l-kebîr). Beyrut : Dâru'l-Fikr.

Reşîd Rızâ (1947). Tefsîrü’l-Kur âni’l-hakâtm (Tefsîrü’l-Menâr). Mısır.

Taberî, Ebu Cafer İbn Cerir Muhammed b. Cerir b. Yezid (1984). Camiu'l-Beyan An Te'vili Âyi’l-Kur'an. Beyrut.

Zemahşerî, Ebu'l-Kâsım Carullah Mahmûd b. Ömer (1997). El-Keşşâf 'An Hakâiki Ğavâmidi't-Tenzîl Ve 'Uyûni'l-Ekâvîl Fî Vucûhi't-Te'vîl, Daru'l-İhya. Beyrut.

RumeliDE Dil ve Edebiyat Araşttrmaları Dergisi Osmanağa Mahallesi, Mürver Çiçeği Sokak, No:14/8 Kadıköy - İSTANBUL / TÜRKIYY 34714 tel: +90 505 7958124, +90 2167730616
RumeliDE Journal of Language and Literature Studies Osmanağa Mahallesi, Mürver Çiçeği Sokak, No:14/8 Kadıköy - ISTANBUL / TURKEY 34714

e-mail: editor@rumelide.com,

phone: +90 505 7958124, +90 2167730616 